Dr KOSTA NIKOLIĆ, naučni savetnik

Institut za savremenu istoriju

Beograd, Trg Nikole Pašića 11

UDK 323(497.11)"1987" 32:929

kostasnikolic@yahoo.com

Милошевић С. 32:929

originalan naučni rad

Стамболић И.

primljeno: 21. septembar 2015.

prihvaćeno: 4. novembar 2015.

\title{
SMENJIVANJE IVANA STAMBOLIĆA SA FUNKCIJE PREDSEDNIKA PREDSEDNIŠTVA SR SRBIJE 1987.*
}

APSTRAKT: $U$ tekstu se analiziraju događaji posle poznate Osme sednice CK SK Srbije kada je Slobodan Milošević pokrenuo akciju za smenjivanje Ivana Stambolića sa čelne državne funkcije u Srbiji. Ciljove akcije bio je osvajanje apsolutne vlasti i uspostavljanje potpuno novih političkih odnosa u Jugoslaviji.

KLJUČNE REČI: Slobodan Milošević, Ivan Stambolić, kult ličnosti, apsolutna vlast

Iako se Osma sednica CK SK Srbije, održana 23. i 24. septembra 1987. godine, obično predstavlja kao početak i kraj ustoličenja Slobodana Miloševića, u pitanju je bila jedna od etapa u posezanju za apsolutnom vlašću. Na toj sednici Milošević je odlučujuću većinu zadobio po klasičnom modelu autoritarnih društvenih i političkih elita: u sukobima pobeđuje onaj ko je „odlučniji“ i „preduzimljiviji“, odnosno bezobzirniji i verolomniji. ${ }^{1}$ Milošević je prvih dana nakon Osme sednice pokrenuo svoju revoluciju, koja je podrazumevala i upotrebu nasilja. To nasilje kasnije je kulminiralo - najpre je bilo primenjeno unutar SK Srbije, pa unutar srpskog društva, da bi na kraju bilo pretvoreno u opšti konflikt sa neistomišljenicima u Jugoslaviji.

* Rad je deo projekta Srpsko društvo u jugoslovenskoj državi u 20. veku - između demokratije i diktature (br. 177016) koji finansira Ministarstvo prosvete, nauke i tehnološkog razvoja Republike Srbije.

${ }^{1}$ O ovoj sednici opširnije videti: Dejan Jović, „Osma sjednica: uzroci, značaj, interpretacije“, u Slobodan Milošević - put ka vlasti. Osma sednica CK SK Srbije - uzroci, tok i posledice (Beograd: Institut za savremenu istoriju; Stirling: Centar za proučavanje evropskog susedstva, 2008), 33-68; Kosta Nikolić, „Osma sednica - kraj borbe za Titovo nasleđe u Srbiji“, u: Slobodan Milošević - put ka vlasti, 121-147 i Slobodan Antonić, Zarobljena zemlja. Srbija za vlade Slobodana Miloševića, (Beograd: Otkrovenje, 2002). 
Iako je Milošević porazio svog dotadašnjeg političkog pokrovitelja i zauzeo njegovo mesto, trebalo je izvršiti i potpunu političku "likvidaciju“ Ivana Stambolića, jer Milošević nije podnosio da mu se neko suprotstavlja, a želeo je i da svim potencijalnim protivnicima pošalje više nego jasnu poruku. Stambolić, međutim, nikako nije hteo da podnese ostavku: „E, to nećete, mislim se. Jedno političko značenje ima smenjivanje, a ostavka sasvim drugo. Možete sa mnom nasilno činiti šta god hoćete, ali nećete komandovati mojom voljom. Želeo sam da budem smenjen, da me razreše dužnosti, a ne da ostavkom potvrdim javne i lažne optužbe“. ${ }^{2}$

Za razliku od Stambolića, Dragiša Pavlović je već 29. septembra, na sednici Predsedništva GK, podneo ostavku: „Imajući u vidu tok i rezultat rasprave na sednici CK SK Srbije, na kojoj sam razrešen dužnosti člana Predsedništva CK SKS, smatram da je politički celishodno da podnesem neopozivu ostavku na funkciju predsednika Gradskog komiteta Saveza komunista u Beogradu“. ${ }^{3}$

Slobodan Milošević je polako učvršćivao svoj položaj. Tako treba shvatiti i sastanak koji je 5 . oktobra održao sa predsednicima međuopštinskih konferencija Saveza komunista. Dogovoren je program angažovanja komunista na realizaciji stavova CK SK Srbije usvojenih na Osmoj sednici, koju je članstvo već ocenilo kao „krupan korak“ u doslednom ostvarivanju politike Saveza komunista Jugoslavije. Milošević je kao posebno važno isticao ostvareno jedinstvo, a diferencijacija je samo jačala to jedinstvo. $\mathrm{Na}$ sastanku je konstatovano da se u organizacijama Saveza komunista „naročito visoko ocenjuje demokratičnost i dostojanstvo rasprave" na Osmoj sednici, kao i to što je izrečen „jasan i odlučan stav“ prema srpskom nacionalizmu. ${ }^{4}$

Već istoga dana održana je sednica Predsedništva Gradskog komiteta, na kojoj se nastavljen proces „diferencijacije“. Na redu je bio Radmilo Kljajić. On je smenjen sa funkcije izvršnog sekretara Predsedništva GK „zbog idejno-političkih propusta" vezanih za aferu povodom lista Student. Osim toga, odlučeno je da se Gradskom komitetu predloži da se Kljajić isključi kako iz samog Komiteta, tako i iz redova Saveza komunista. ${ }^{5}$

Logika "klasne borbe" bila je neumoljiva. Na redu su bile promene $u$ dnevnom listu „Politika“. Na sednici Predsedništva republičke konferencije

${ }^{2}$ Ivan Stambolić, Put u bespuće: odgovori Ivana Stambolića na pitanja Slobodana Inića, (Beograd: Radio B 92, 1995), 253.

3 „Драгиша Павловић поднео оставку“, Полиииика, 30. 9. 1987, 1 .

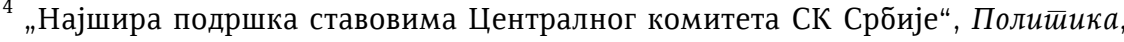
6. 10. 1987,1 .

5 „Смењен Радмило Кљајић“, Борба, 7. октобар 1987, 3. O aferi Student u kontekstu Osme sednice videti: Dragomir Bondžić, „Osma sednica i Beogradski univerzitet“, u: Slobodan Milošević - put ka vlasti, 149-160. 
Socijalističkog saveza, održanoj 12. oktobra, raspravljalo se o smeni Ivana Stojanovića sa funkcije direktora ove izdavačke kuće „zbog neodgovornosti u vršenju ove dužnosti“. Sednici su prisustvovali i Slobodan Milošević i Ivan Stambolić, što je samo pokazivalo da je u pitanju bila dublja pozadina smenjivanja direktora „Politike“. ${ }^{6}$ Radna grupa koja je pripremala ovu sednicu, ocenila je da „drug Ivan Stojanovićc nije celovito, odgovorno i dosledno izvršavao obaveze koje proizilaze iz njegove funkcije i da nije blagovremeno davao predloge samoupravnim organima za otklanjanje problema. Zbog toga je došlo do „odstupanja od ciljeva i zadataka NO Politika i programske koncepcije utvrđene osnivačkim aktom, što je dovelo do različitog pristupa, pa i suprotstavljenog odnosa pojedinih redakcija na pojedine društvene teme". ${ }^{7}$

Ipak, Stojanović se nije lako predao. Iako je pre početka sednice podneo molbu „da bude razrešen dužnosti“, odlučio je da diskutuje. Govorio je da je postupao po Zakonu o javnom informisanju kada je dozvoljavao polemike u listu, što je očigledno nerviralo Miloševićevu struju, da je cela kuća „Politika“ ekonomski stabilizovana: „Meni se prebacuje da sam odgovoran i zbog toga što se NO Politika ne razvija. To moram da odbacim kao neosnovano, jer se takva ocena može danas dati većini direktora i u Srbiji i $\mathrm{u}$ zemlji. Imajte u vidu da sam samo devet meseci direktor Politike, pa bar negde zabeležite da sam bar nešto uspeo da uradim, naravno ne sam". ${ }^{8}$

Ovakva Stojanovićeva reakcija izazvala je lavinu optužbi, ali i odbrane. Najglasniji u napadima bio je Živan Stojković. Tražio je da Stojanović bude smenjen a ne razrešen „jer je imao vrlo loš odjek u javnosti i nepovoljno reagovanje među narodom". Na drugoj strani, istaknuti umetnik Ljuba Tadić je govorio kako je „neumesno i politički neodrživo da nas stalno opominjete i zastrašujete partijskim stavovima i zadacima. Ja Socijalistički savez shvatam kao najširi demokratski front i nisam postao član ovog Predsedništva da bih se pripremio za člana partije“. 9

Odmah je kritikovan od Bogdana Trifunovića koji je Tadića optužio da odavno iznosi diskvalifikacije na račun radnih tela Republičke konferencije i njenog predsednika: „Ljuba Tadić je stigao dotle da zamera meni zbog toga što vodim računa o zaključcima $\mathrm{SK}$, tj. njegovih legalno izabranih organa. Zašto ja to ne bi trebalo da vodim računa i zašto mi svi ostali ne bi trebali to da radimo? Savez komunista je deo Socijalističkog saveza. Kakve

${ }^{6}$ O diferencijaciji u sredstvima javnog informisanja nakon Osme sednice videti: Vladimir Petrović, „Uloga medija u učvršćenju vlasti Slobodana Miloševića“, Istorija 20. veka, br. 2, (2013), 194-199.

${ }^{7}$ Полийика, 13. 10. 1987, 1.

8 „О стању у НО Политика“, Политичка, 13. 10. 1987, 5.

${ }^{9}$ Ис $\bar{u} 0$. 
su to, onda, olake optužbe da neko često vodi računa o zaključcima Predsedništva CK SKS?"10

Trifunovića je snažno podržao i Slobodan Vučetić, uz primetnu dozu cinizma („ne može se poistovetiti pozicija direktora u jednoj fabrici obuće i mesto direktora 'Politike'“). Glavna uloga direktora, tvrdio je Vučetić, bila je da utiče na osnovne tokove uređivačke politike. Nenad Ristić je tražio od Stojanovića da preuzme bar deo kritike, a Petar Damnjanović je zamerio na načinu pripreme ove sednice i razlogu njenog sazivanja: „Narod u današnje vreme prosto vapi za krivcima koji će da budu kažnjeni. To je kao nekakav sigurnosni ventil, nekakva potreba, nešto iznad racionalnog. Zbog toga su svu pažnju javnosti zaslužili i krivci koje je apostrofirao Centralni komitet, a to je danas Ivan Stojanović. Čitava ova priča oko odgovornosti direktora 'Politike' se među radnicima Rakovice ne doživljava kao neki veliki pomak napred. Izabrano je upravo najgore moguće vreme za jednu ovakvu stvar, kada bi se trebalo usredsrediti ka centralnim pitanjima, a to je ostvarivanje dohotka". ${ }^{11}$

Pošto su se sve više javljali oni koji su branili Ivana Stojanovića (Sava Kržavac je za smenu direktora Politike tražio „debelo obrazloženje“) morao je da interveniše Milošević. U već prepoznatljivom stilu hitnosti po svaku cenu, rekao je kako je „van svake sumnje da nema nikakvih razloga za bilo kakva odlaganja“, a da demokratska praksa zahteva odgovornost: „Iz ove krize bez promena ne možemo izaći. A mi se suočavamo i sukobljavamo danas i poslednjih godina i poslednjih meseci sa praksom da niko nizašta nije odgovoran i da niko nikome ne odgovara. To nije demokratska praksa. Demokratska praksa je kada oni koji su na demokratski način došli na odgovorna mesta odgovaraju onima koji su ih izabrali za sve što čine na tim svojim mestima". ${ }^{12}$

I ovoga puta Milošević nije propustio da ukaže na neophodnost „jedinstva socijalističkih snaga“ kako bi društvo brže izašlo iz političke, ekonomske i moralne krize: „A do jedinstva se ne može doći ako se prethodno ne izvrši diferencijacija pre svega u Savezu komunista a onda u čitavom frontu socijalističkih snaga. Zbog toga je nama nužno, a i zbog toga je to najteži korak koji moramo izvršiti, da sprovedemo diferencijaciju na liniji politike Saveza komunista, na liniji onih opredeljenja koja imamo još od 10. kongresa do poslednjih dana i do poslednjeg plenuma CK SK Srbije". ${ }^{13}$

Potom je govorio Ivan Stambolić, dosta nepovezano i neodređeno, bez nekog jasnijeg stava. Samo je naglašavao da treba poštovati zakonsku

\footnotetext{
${ }^{10}$ Исйо.

${ }^{11}$ Исйо.

12 „Људе узнемирава криза а не штампа“, Полийика, 13. 10. 1987, 6.

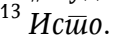


proceduru: „Kada su u pitanju ljudi i njihove odgovornosti, nepoštovanje zakona se ne može svoditi na nepoštovanje formalnosti. Jer nepoštovanje formalnosti je nepoštovanje suštine. I drugo. Treba se strogo držati tih formalnosti koje su u ovom slučaju suština zato što to nepoštovanje (ne samo onih koji sa dovoljnim stepenom odgovornosti ne vrše svoje funkcije) može izazvati nesigurnost, pa i strah i ugušiti inicijativnost i hrabrost i onih koji su odgovorni. Zbog toga i predlažem i tako se i izjašnjavam, jer na osnovu svega rečenog još nisam siguran u neke stvari u vezi sa tim. Ostavku treba usvojiti. Usvaja se ostavka, znači volja koju izražava nosilac te funkcije. Zato ću i sam glasati za usvajanje ostavke i na osnovu nje za razrešenje. Ne bih glasao za obrazloženje imajući u vidu sporove koje je izazvalo. I na tome mi se čini da možda postoji potpuno jedinstvo. Imamo elemenata za usvajanje ostavke i razrešenje, imamo samo njegovu molbu i to je njegova volja. Sačekajmo, mnogi drugovi su govorili, ima i nekih nepreciznosti i preterivanja. Hajde kroz to da prođemo normalno i regularno i da budemo mirni“" ${ }^{4}$

$\mathrm{Na}$ kraju se, posle više od četiri sata diskusije, pristupilo formalnom glasanju. Za predlog da se Ivan Stojanović razreši dužnosti direktora „polazeći od suštinske političke ocene iz informacije radnih tela Predsedništva Socijalističkog saveza" glasalo je 23 od 35 prisutnih; za predlog Ivana Stambolića da se usvoji ostavka koju je ponudio sam Stojanović, glasalo je šest članova Predsedništva RK SSRN Srbije. ${ }^{15}$

Nije se mnogo razmišljalo o novom direktoru. On je odranije bio poznat - Živorad Minović koji je, kao glavni i odgovorni urednik, već bio najupućeniji „u problematiku novinske organizacije u celini“, pa njegovu kandidaturu „nije trebalo detaljnije obrazlagati“. Pod tekućim pitanjima nagovešteno je da će doći i do smena u NIN-u, i to ne samo što je Mirku Đekiću, glavnom i odgovornom uredniku, istekao mandat, već i zbog „mnogih slabosti i promašaja u uređivačkoj politici“. Vojislav Mićović je istakao da se u ovom listu pojavio „niz tekstova koji su svojom političkom kontroverznošću i ideološkom opredeljenošću, čije je nesaglasje sa uređivačkom koncepcijom veoma izraženo, izazvali nedoumice, nesaglasnosti i kritike“. ${ }^{16}$

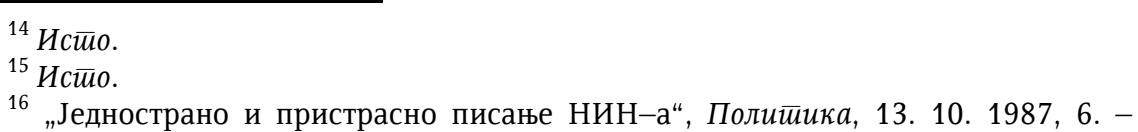
Mićovića su posebno iznervirali tekstovi koji su ocenjivali Osmu sednicu: „Takav način ponašanja je bez presedana. On ne doprinosi raščišćavanju magle, on je stvara. On ne doprinosi građenju jedinstva već ga razbija, on ne doprinosi okupljanju u zajednički front borbe, on ga razdvaja i suprotstavlja. Izgleda da NIN-ovi autori nisu u sednici CK videli ništa drugo već borbu za likvidaciju ljudi. Analizom ovih tekstova ne bih želeo da vas zamaram. Želim samo da kažem da mi kao osnivač NIN-a ne možemo da stojimo iza ovakvih tendencija u uređivačkoj politici i da moramo da tražimo raspravu o odgovornosti za takvu politiku“. (Isto). 
Predsedništvo Gradskog komiteta SK Beograda postalo je krajem 1987. najsnažnije uporište Slobodana Miloševića u učvršćivanju vlasti unutar SK Srbije. Na sastancima ovog foruma branjene su „ideje Osme sednice“ i najavljivane nove akcije u okviru procesa „idejne diferencijacije“. Osim aktuelne „idejno-političke situacije“, kadrovska politika bila je centralna tema. Tako je bilo i na sastanku održanom 15. oktobra.

Dominirala je ocena Osme sednice, a posebno se naglašavalo kako je ona imala veliki odjek ne samo među komunistima Beograda, već i kod „radnih ljudi i građana“. Slobodan Jovanović, koji je ostao na mestu glavnog urednika Politike ekspres, tako piše: „Narod u Plenumu prepoznaje Savez komunista kakav mu treba. Svedoci smo psihološkog šoka da u odjeku Plenuma ljudi vide rešenost da se sprovede ono što se govori i dogovori. Traži se konkretizacija svake odgovornosti kao demokratski čin i za delo i za reč, za učinjeno i za neučinjeno. Komunisti i radni ljudi Beograda Osmu sednicu su doživeli kao krupan korak u doslednom pristupu ostvarivanju politike SKJ, a reč je o odlučnom sukobljavanju sa oportunizmom koji onemogućava SK da vodi energičnu akciju za ostvarivanje utvrđene politike“. ${ }^{17}$

Na sednici Gradskog komiteta SK Beograda održanoj 13. novembra 1987. za novog šefa beogradske partijske organizacije izabran je Radoš Smiljković, što treba razumeti kao nagradu za njegove krute, dogmatske stavove. Za Smiljkovića je glasalo 66 članova GK, a sedam je bilo protiv. Tako je Gradski komitet podržao odluku svog Predsedništva da na listi bude samo jedan kandidat, iako su još predlagani Mihailo Milojević i Slobodanka Gruden. Predlog da se izađe sa samo jednim kandidatom, Bora Kuzmanović, sekretar Predsedništva, branio je principom „kolektivnog rada i odlučivanja, odgovornosti i jedinstva“ u ovom telu: „Stav da to treba da bude Radoš Smiljković proistekao je iz ocene o njegovom dosadašnjem društveno-političkom i ukupnom angažovanju, kao i o njegovim radnim i naučnim rezultatima". ${ }^{18}$

Miloševićev aktivizam došao je do punog izražaja i ogledao se $u$ naporu da se javnost uveri kako se stvari ipak kreću sa mrtve tačke. U tom cilju održana je 19. novembra sednica Predsedništva CK SK Srbije na kojoj se razgovaralo o zaustavljanju iseljavanja sa Kosova. Oslonac je tražen u jugoslovenskom programu, o čemu je u uvodu govorio Jurij Bajec: „Činjenica da Program donosi Skupština Jugoslavije izražava odgovornost federacije da u skladu sa svojim ustavnim ovlašćenjima obezbeđuje njegovu realizaciju. Međutim, Program istovremeno podrazumeva znatno veću odgovornost

\footnotetext{
17 „Чланство СК је охрабрено“, Политичка, 16. 10. 1987, 1.

${ }^{18}$ Полийика, 14. 11. 1987, 1.
} 
subjektivnih snaga na Kosovu za sopstveni razvoj. Zalažemo se da se na toj osnovi obezbedi dalja dosledna, odlučna radna i politička diferencijacija“. ${ }^{19}$

Bajec se založio i za šire otvaranje Kosova prema Jugoslaviji i Jugoslavije prema Kosovu, kako bi se iskorenio albanski nacionalizam. I ustavne promene bile su neophodna karika tog procesa: „Prepreka većem i neposrednijem doprinosu republičkih organa u ostvarivanju ustavnosti i zakonitosti na Kosovu jesu i neka od ustavno-pravnih rešenja u ustavima SFRJ i SR Srbije. Ta rešenja onemogućavaju da republički organi neposredno deluju i preduzimaju mere na Kosovu. Zato i prilikom razmatranja predloga ovog programa, treba ukazati na sav značaj neophodnih promena u Ustavu SR Srbije. Pitanja funkcionisanja klasičnih državnih funkcija radi sigurnosti građana, porodica i dece toliko su važna da pred njima padaju doktrinarna i sva druga natezanja oko ničim osporenih prava pokrajina u SR Srbiji““. ${ }^{20}$

Azem Vlasi je takođe podržao jugoslovenski program i isticao da se na Kosovu stvara nova svest: „Progresivne snage, ljudi svih naroda i narodnosti uviđaju da taj problem iseljavanja objektivno i neposredno stvara teške i dalekosežne političke, društvene i druge posledice, pa da je iz tih razloga i interes progresivnih snaga na Kosovu da se proces iseljavanja zaustavi, a stvore uslovi da se u rodni kraj vrate i oni koji su ga napustili, a žele da se vrate iz bilo kog kraja Jugoslavije. Ta nova klima predstavlja pogodno tlo za efikasnu realizaciju predloženih mera i aktivnosti. Nadu da će se one uspešno ostvariti daje i povećana efikasnost društvene i političke akcije na Kosovu u poslednje vreme, kao i uspostavljena praksa saradnje i zajedničkog rada organa Republike i Pokrajine". ${ }^{21}$

Milošević je nastojao da teret kosovske krize prebaci na jugoslovenski nivo, kako iz političkih, tako i iz ekonomskih razloga: „Ekonomski i društveni aspekt ovog programa, kako u pogledu transfera materijalnih sredstava koja će biti obezbeđena za najbrži razvoj Kosova, tako i u pogledu društveno-ekonomskih odnosa koji će se ostvariti, predstavljaju bez sumnje nov kvalitet koji daje daleko veću sigurnost i izvesnost da će se ta sredstva efikasno upotrebiti i da će rezultirati u stvarnim efektima ekonomskog i društvenog razvoja Kosova“. ${ }^{22}$

Od svih komunista Milošević je tražio da dosledno i odgovorno realizuju Program, uveravajući i sebe i druge da je preokret na Kosovu moguć, što će označiti nov način njegovog političkog delovanja - davanje neodgovornih obećanja koja se brzo zaboravljaju: „Mislim da možemo da kažemo da je to početak ekonomskog ali i socijalnog i političkog preobražaja Kosova

\footnotetext{
${ }^{19}$ Политичка, 20. 11. 1987, 5

${ }^{20}$ Истио.

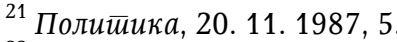

22 „Почетак преображаја Косова“, Полийика, 20. 11. 1987, 1.
} 
na način na koji to treba da čini jedna razvijena zemlja na pragu 21. veka. Dakle, reč je o svestranom i celovitom pristupu rešavanju problema koji ima u vidu svaku dimenziju razvoja i koji ne zatvara stvari samo u političke forume i samo na neke aspekte pitanja o kojima je reč, nego se okreće ka svestranom i celovitom razvoju i rešavanju krize. To je program koji ima šansu da okupi sve stvaralačke snage u savladavanju problema krize za koju smo se svi složili da najozbiljnije potresa Jugoslaviju“". ${ }^{23}$

Slobodan Milošević je bio u punoj ofanzivi, a istorizacija Osme sednice kao prelomnog događaja u bržem rešavanju političke i ekonomske krize bila je u punom jeku. Istovremeno, stvarao je sliku o sebi kao o čoveku akcije koji ne okleva i ne gubi vreme u „beskorisnim“ razgovorima.

Toj temi Milošević je posvetio dosta prostora i prilikom posete Mašinskoj industriji u Nišu 23. novembra 1987. godine. Demagogije nije, kao i uvek, nedostajalo: „Ne želim danas da govorim o ekonomskoj i socijalnoj krizi u kojoj se nalazimo. Njenu težinu oseća svaki kolektiv, svaki građanin naše zemlje. Nikome nije više do analize teškoća koje imamo i svi mi i naše društvo. A pogotovu što od te analize nema koristi. Ono što je sada na dnevnom redu našeg društva i politike, jeste - šta da se radi, šta da učinimo da što pre ostavimo za sobom ova teška vremena: da porodica može da živi od zarađenog, da privreda može normalno da se reprodukuje, da se uspešno rešavaju pitanja obrazovanja, nauke, zdravstva i kulture, da najmlađa generacija ima vedriju perspektivu, da penzioneri ne moraju da razmišljaju da li će ček primiti unapred ili unazad“. ${ }^{24}$

Milošević je i dalje sledio logiku „klasne borbe“ - strukturne promene sistema nisu bile toliko neophodne, koliko obračun sa sopstvenim oportunizmom. Osim toga, pristup ustavnim promenama znatno je promenjen $u$ odnosu na Stambolićevu politiku, što će se iskazati u narednom periodu: promena Ustava bila je "stvar naroda a ne stvar rukovodstva“. U tom kontekstu Milošević je tumačio i Osmu sednicu: ona se odvijala u duhu opredeljenja za bolje i progresivnije: „Ta sednica je početak likvidiranja politike odlaganja problema, nepoštovanja dogovora, nezameranja drugima. Politike koja je jedan od temeljnih uzroka naše krize. Zato smo, dakle, na sednicu CK morali da stavimo i sebe same, da među sobom otvoreno i javno raspravljamo o tome ko $\mathrm{u}$ ovo teško doba može da nosi njegovo breme $\mathrm{i}$ vodi bitku za bolje dane, a ko to ne može“". ${ }^{25}$

Podela na Osmoj sednici izvršena je na liniji borbe za jedinstvo SK Srbije, pa je, isticao je Milošević, zato i izvršena diferencijacija prema

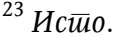

24 „Немамо намеру да скрштених руку чекамо промене“, Политиика, 24. 11.

${ }^{25}$ Политичка, 24. 11. 1987, 5.
} 1987, 1. 
„drugovima koji namere da dogovor ostvarimo uopšte nisu ni imali. Za njih je i dalje na redu bila samo diskusija, 'demokratski dijalog', a neki su očigledno i kalkulisali, kako će oni sami u toj bici da prođu“. Istovremeno je Milošević poručio šta se sprema Ivanu Stamboliću: „Osma sednica CK SK Srbije je veoma prisutna ne samo u partijskoj, već i u najširoj javnosti naše republike. Ona nailazi na podršku i gotovo u svim sredinama izražavaju se zahtevi da se diferencijacija izvrši do kraja“. ${ }^{26}$

Signal je dat i već sutradan reagovalo je Predsedništvo Gradskog komiteta SK Beograda. Greh zbog koga je Stambolić morao da bude politički pokopan, bilo je njegovo pismo članovima Predsedništva GK od 17. septembra, kada je podržao Dragišu Pavlovića. Predsedništvo je, naravno, samo poštovalo ono što su osnovne organizacije SK u Beogradu, „komunisti u radnim kolektivima, mesnim zajednicama i neprivrednim institucijama“, tražile od novog partijskog rukovodstva Beograda: „Kako se opredeliti prema činjenici da je drug Ivan Stambolić svojim pismom Predsedništvu GK dao neprincipijelnu podršku Dragiši Pavloviću, neposredno pred održavanje javne sednice". ${ }^{27}$

Predsedništvo GK javno je saopštilo da smatra kako je Stambolićev postupak „bio sračunat na to da metodom pritiska, polazeći od autoriteta svoje funkcije koju vrši, onemogući demokratsku raspravu o odgovornosti Dragiše Pavlovića. Iako su članovi Predsedništva GK OSK Beograda i ranije znali za bliske odnose između Stambolića i Pavlovića, ipak nisu mogli da shvate da će u svojoj pristrasnoj podršci Stambolić ići toliko daleko da bi došao u sukob sa principima SK". ${ }^{28}$

Istovremeno je podržan i postupak nekolicine članova Predsedništva GK na Osmoj sednici koji su o tome obavestili Centralni komitet i „onemogućili eventualnu manipulaciju i sa samim Predsedništvom CK SKS“. Predsedništvo je, tako, zaključilo da je Stambolić „izgubio neophodan ugled među komunistima i da je takav postupak u moralnom i političkom pogledu nespojiv sa funkcijom predsednika Predsedništva SR Srbije“. ${ }^{29}$

$\mathrm{Na}$ udaru se našao i Bogdan Bogdanović, nekadašnji beogradski gradonačelnik, zbog pisma koje je poslao srpskom Centralnom komitetu. Bogdanović je, po oceni Predsedništva GK, „proizveo nesumnjivo negativno dejstvo i političku štetu“. Takođe je bilo „jasno“ da je Bogdanović, optužujući CK za dogmatizam i staljinizam, doveo u pitanje svoj status člana Centralnog komiteta izabranog iz Beograda: „Bogdan Bogdanović kao član

${ }^{26}$ Истйo.

27 „Поступак Ивана Стамболића неспојив са функцијом председника Председништва Србиије“, Политиика, 25. 11. 1987, 1.

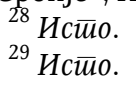


Saveza komunista i istaknuti umetnik i profesor, kao čovek koji je bio na najodgovornijoj funkciji u gradu, mora u daljim raspravama o svojim stavovima da ima u vidu da iza sebe nema podršku ogromne većine komunista Beograda". ${ }^{30}$

Zatim je 26. novembra zasedao Gradski komitet. Na dnevnom redu bila su „Aktuelna pitanja ostvarivanja kadrovske politike u složenim društveno-ekonomskim uslovima“. Gradski komitet jednoglasno je podržao stavove svog Predsedništva o odgovornosti Ivana Stambolića. Radoš Smiljković: „Ti zaključci su dobro primljeni i traži se još energičnije delovanje u sferi raščišćavanja pitanja u svim oblastima, a pre svega u ovoj, gde su u pitanju kadrovi, jer je svima jasno da bez odgovarajućih kadrova ne mogu se donositi ni nove odluke, a pogotovu se ne mogu probijati novi putevi, novi pravci koji će nam omogućiti da savladamo krizu“."31

$\mathrm{Na}$ ovoj sednici Radmilo Kljajić je isključen iz Saveza komunista. Njegova krivica bila je u odbrani „Studenta“ kada je stvorio zabunu u javnosti i diskreditovao organe SK, „osporavajući im pravo da o pojedinim političkim pitanjima i pojavama zauzimaju stavove" optužujući ih za dogmatizam. Ulogu Kljajićevog dželata dobio je Dušan Mitević: „Drug Radmilo Kljajić je bio u našem Predsedništvu Gradskog komiteta sekretar za javno informisanje, a vremenom je postepeno postao simbol ličnog sekretara za tajne poslove, za deo politike ispod stola koja se vodila u Gradskom komitetu, za dogovor iza zatvorenih vrata, postao je čovek za poslove najvećeg poverenja, stroge tajnosti i velike društvene opasnosti kako se na kraju pokazao u svim ovim analizama. Dakle, ne radi se o drugu koji odgovara za svoja demokratska shvatanja, zato što je mislio svojom glavom, kako voli da kaže za sebe, što je bio u sukobu sa moćnicima. Ja znam da je to nepopularno što ću reći, ali ja mislim da mi tu mimikriju drugu Kljajiću ne smemo da dozvolimo, tu zamenu teza. Ako bismo tu pokazali popustljivost, bili bismo naivni, a ne bi stekli imunitet da se to u našim odnosima dalje ne ponavlja. Zato, isključujući danas druga Radmila Kljajića iz Saveza komunista, mi manifestujemo rečju i delom i glasanjem da želimo da iz Saveza komunista izbacimo i to što predstavlja njegov slučaj“. ${ }^{32}$

Novi staljinizam bio je u punom zamahu. Radmilo Kljajić je mogao da izbegne ovakvu sudbinu, ali je odbio Mitevićev predlog da se ,još jednom izjasni politički o ulozi, karakteru i liku druga Pavlovića“. Mitević je govorio

${ }^{30}$ Исйо. - Pismo Bogdana Bogdanovića nije objavljeno u Beogradu, ali jeste u Zagrebu. Videti: Bogdan Bogdanović, „Jezičke zamke. Pismo CKSKS“, u: Mrtvouzice. Mentalne zamke staljinizma, (Zagreb: August Cesarec, 1988), 11-58.

27. 11. 1987, 1.

31 „Београду су потребни смели и способни људи на функцијама“, Полийuка,

32 „Лични секретар за тајне послове“, Политиика, 27. 11. 1987, 7. 
kako je na taj način samo želeo da pomogne istini, „koja je apsolutno poznata svima nama“. Mitević je zaista prevazišao samog sebe, naglašavajući da se isključenjem Kljajića, u stvari, nastavlja proces odbrane „revolucionarnog lika i dela druga Tita“. ${ }^{33}$

Konkretna akcija usledila je odmah posle Dana republike, a povod je dao sam Ivan Stambolić svojim zahtevom od 26. novembra da se objavi njegovo pismo Predsedništvu Gradskog komiteta SK Beograda od 17. septembra, jer je to pismo postalo „predmet rasprava na zatvorenim sednicama i teških kvalifikacija u javnim saopštenjima" Predsedništva GK. Izgleda da je Stambolić bio spreman da podnese ostavku ako se njegovo pismo objavi. Predsedništvo GK na sednici od 4. decembra nije prihvatilo da se pismo objavi, ali je odlučilo da objavi „činjenice i okolnosti koje osvetljavaju pozadinu postupka Ivana Stambolića“ i svoje stavove u vezi sa „njegovim ukupnim ponašanjem neposredno pre i posle 8 . sednice CK SK Srbije“.

Predsedništvo je ocenilo da je Stambolićevo pismo „bilo sračunato na to da se pre zakazane sednice Predsedništva GK na čijem je dnevnom redu bilo istupanje Dragiše Pavlovića pred glavnim urednicima, obezbedi podrška Predsedništva stavovima iz tog istupanja“. Tako je Stambolić konfrontirao Predsedništvo najveće partijske organizacije u zemlji sa Predsedništvom CK SK Srbije, želeći da stvori rascep u Savezu komunista: „Ovaj čin Ivana Stambolića trebalo je da bude odlučujući u nizu zgusnutih planiranih akcija kojima se stvarala osnova da se ospore i dovedu u pitanje stavovi i odlučne akcije Predsedništva CK SKS u sprovođenju politike Saveza komunista na Kosovu, kao i u odbrani ličnosti i revolucionarnog dela druga Tita. Slanjem tajnog pisma Ivan Stambolić je liderski samouvereno založio svoj ugled i autoritet predsednika Predsedništva radi odbrane stavova koji su na 8. sednici CK SKS ocenjeni kao protivljenje politici Saveza komunista. Način na koji je to učinio bez presedana je u praksi Saveza komunista i tuđ je biću i principima organizovanja i delovanja radničke avangarde. Nije bilo primera da jedan čovek tako sebe stavi iznad organa i organizacija SK“. ${ }^{34}$

Naravno da Stambolić nije bio kriv za iznošenje svog mišljenja, već za „besprincipijelni pokušaj nametanja svog mišljenja“. I ovoga puta pribeglo se metodu obračuna. Predsedništvo je saopštilo da ne poseduje original Stambolićevog pisma jer ga je Dragiša Pavlović odneo sa sobom! Pismo koje je sam Stambolić ponudio za objavljivanje, po mišljenju Predsedništva nije bilo istovetno sa onim što je pročitao Dragiša Pavlović 17. septembra: „Slanjem ovog drugog pisma, Ivan Stambolić je svojoj praksi tajnih pisama radi vršenja pritiska sa pozicije autoriteta funkcije, dodao i pokušaj obmanjivanja javnosti. Nastojeći da skrene pažnju javnosti na sadržinu tog pisma,

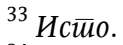

34 „Лидерско противљење политици СК Србије“, Борба, 5-6. 12. 1987, 5.
} 
pokušao je da širinu kritike koja mu se upućuje za birokratsko ponašanje, privatizaciju kadrovske politike i kalkulantsko oklevanje u sprovođenju zaključaka o Kosovu, usmeri u drugom pravcu“. ${ }^{35}$

Predsedništvo je ocenilo da Stambolićeva namera da ovo pismo objavi „predstavlja samo deo njegovog ukupnog delovanja posle 8. sednice koje ide linijom prikrivenog suprotstavljanja zaključcima ove sednice. Ivan Stambolić nije iskoristio ni jednu priliku da podrži i pomogne Savezu komunista u ostvarivanju zaključaka 8 . sednice. Zato započeta diferencijacija uliva nadu da će SK uspešno osnažiti svoju idejnu i političku sposobnost kao uslov za izlazak iz krize putem socijalističkog samoupravljanja, a ne putem birokratske uzurpacije i samovolje. Ivan Stambolić dovodi sebe $u$ situaciju da se postavlja pitanje njegove idejno-političke odgovornosti i to kao člana Saveza komunista". ${ }^{36}$

Akciju na rušenju Ivana Stambolića aktivno je pomogla i Televizija Beograd. Tako je u udarnom terminu, u večernjem Dnevniku u subotu 5. decembra, Slobodanka Gruden objašnjavala stavove Predsedništva GK. Odgovarajući na pitanje urednika Dnevnika Gorana Milića povodom stavova GK posle zahteva Ivana Stambolića da se objavi njegovo pismo, rekla je: „Bili smo primorani da damo ovo saopštenje, koje je izraz tri-četiri radna sastanka, gde se $u$ atmosferi izuzetne tolerancije, discipline i odgovornosti vodilo računa o svakom članu SK, koji je jednak pred Partijom, bez obzira na kojoj se funkciji nalazio, da dođemo do istine kako treba da se ponašamo.

Ono što moram da Vam kažem da nije dobro iz svega toga izašlo, to što je pojedinac, bilo ko da je on, ovoga puta je to Ivan Stambolić, možete sutra da budete Vi ili ja, nema pravo da se nametne iznad organa, iznad svoje partije i iznad svog naroda. Ovoga puta je on to, u stvari, uradio. Oštrina nije oštrina Gradskog komiteta, oštrina je praktično čitavog članstva SK koje na određeni način ovakvo stanje više ne može da podnese i ja moram da Vam kažem da je meni žao što, u stvari, zamaramo ovaj naš narod i ovo članstvo ovom pričom sada, a što ne razgovaramo o onom što je bitno, a to je kako živeti, kako izaći iz ove političke, ekonomske, moralne i etičke krize. To je suština toga“. ${ }^{37}$

Zatim je reagovala Stambolićeva partijska baza. Predsedništvo Opštinskog komiteta SK Starog grada podržalo je ocene o Stambolićevom „liderskom ponašanju“ i tražilo je od njega da podnese ostavku, „kao čin lične odgovornosti za učinjene greške u radu“. Ukoliko se to ne bi dogodilo,

\footnotetext{
${ }^{35}$ Истио 0.

${ }^{36}$ Исйо. - Стамболићево писмо објавила је Борба и оно јесте било идентично са оним што је Драгиша Павловић прочитао 17. септембра. Полийика писмо није објавила.

${ }^{37}$ „Нико не може изнад Партије и народа“, Полишика, 7. 12. 1987, 5.
} 
„trebalo bi da se kroz javne forume i organe u socijalističkom samoupravnom sistemu pokrene postupak za njegovo smenjivanje“".38

Milošević nije imao previše poverenja u „javne forume“. Pošto je Stambolić i dalje odbijao da podnese ostavku, krenulo se u tajnu akciju. Ponovo je glavni akter bio Nikola Ljubičić. Još uvek legitimnom šefu države predlaže sastanak "grupe drugova" kako bi se razgovaralo o zahtevima za Stambolićevu ostavku. General je pokušavao i da zakaže sednicu Predsedništva republike. Sastanak je ubrzo održan, daleko od očiju javnosti. Na njemu su, osim Stambolića, bili Ljubičić, Dušan Čkrebić, Milošević, Bogdan Trifunović i Aleksandar Bakočević.

Sastanak je otvorio ostareli general, još uvek željan vlasti. Upozoravao je na „nove okolnosti“, na jedinstvo koje se mora održati po svaku cenu. Govorio je o sve većem nezadovoljstvu radom Predsedništva republike. Stamboliću je zamerio što nijednom rečenicom neće da u javnosti podrži Osmu sednicu. Oslanjao se na stavove Gradskog komiteta SK Beograda ( „to je vrlo bitno, jer je Beograd izabrao Ivana, on je beogradski kadar"). Tražio je da Stambolić podnese ostavku na čelnu funkciju a da ostane član Predsedništva. Za novog predsednika Predsedništva predložio je generala Petar Gračanina. ${ }^{39}$

Milošević je isticao da posredi nije personalno pitanje, već to što je na Osmoj sednici Stambolić „okrenuo kadrove iz državnih struktura protiv Partije“. Isticao je i da je lično ublažavao kritiku prema Stamboliću očekujući njegov doprinos jedinstvu, ali pošto on "deluje po svome“ i pošto je želeo da razbije Partiju, treba da podnese ostavku. Stambolić se složio da nije u pitanju personalni sukob već ideološki. Kosovo je demagoški iskorišćeno „za ubiranje nacionalnih simpatija i podrške u goloj borbi za vlast“. U pitanju je bio njegov sukob sa „dogmatskom autoritarnošću i razarajućom voljom za političkim obračunavanjem i uništavanjem". ${ }^{40}$

Kada je general Ljubičić shvatio da od ostavke nema ništa, za 14. decembar zakazana je 33. sednica Predsedništva na kojoj je trebalo da bude razrešen njegov predsednik. Mada je planirano da to bude rutinski sastanak, razvila se neprijatna debata. Najpre je kosovski predstavnik Bajram Seljani pitao šta je istina o Stambolićevom pismu Gradskom komitetu? Ko je falsifikator, Stambolić ili vodeći ljudi Gradskog komiteta? Ljubičić mu je rekao da se ne treba baviti sadržajem pisma: „Ono što predlaže drug Seljani, čini mi se da nema nikakve svrhe. To će nas odvesti u diskusije koje nismo u stanju da razjasnimo danas. Zato predlažem da uđemo u konkretan posao, da prihvatimo ovo što je na dnevnom redu, ovo pitanje razrešenja druga

\footnotetext{
38 „Непримерено и лидерско понашање“, Полийика, 8. 12. 1987, 6.

${ }^{39}$ I. Stambolić, Put u bespuće, 255-256.

${ }^{40}$ Isto, 258-259.
} 
Ivana. Tada bi smo normalizovali rad Predsedništva, a time ćemo najbolje pomoći Ivanu“."

Ako je verovati Stamboliću, čak je i on nagovarao Vukoja Bulatovića da glasa protiv njega, ali je ipak na samoj sednici rezultat glasanja bio „nerešen“: za razrešenje je glasalo šest članova (Vukoje Bulatović, Aleksandar Mitrović, Zoran Pjanić, Svetislav Božić, Ljubiša Igić i Slobodan Milošević); protiv je bila Ljubinka Trgovčević, a četvoro predstavnika pokrajina se uzdržalo (Radovan Međedović, Nandor Major, Bajram Seljani i Šefćet Jašari); sam Stambolić nije glasao, što je bilo njegovo pravo: „Nikoli Ljubičiću tresle su se ruke. Pita šta da se radi. Pravni savetnik kaže: Mora većina! Presečem mučenje. Zaključujem da je Predsedništvo razmotrilo inicijativu i predlog za razrešenje predsednika Predsedništva i da je taj predlog usvojilo. I Ljubičić i Milošević su to otćutali“. ${ }^{42}$

Tako je smenjen Ivan Stambolić. Svima je laknulo: „Prešli smo u moju kancelariju da popijemo piće. I Miloševića sam častio. Onda sam se pozdravio i otišao". ${ }^{43}$

Javnost u Srbiji je o smeni svog predsednika obaveštena kratkim saopštenjem: „Predsedništvo SR Srbije razmotrilo je situaciju nastalu povodom javno izrečenih kritika predsedniku Predsedništva Ivanu Stamboliću i s tim u vezi teškoće u ostvarivanju funkcija Predsedništva, kao i u ostvarivanju koordinacije i saradnje organa i organizacija Republike. Polazeći od toga, kao i od konsultacija obavljenih u organima i organizacijama Republike, Predsedništvo SR Srbije donelo je odluku o razrešenju Ivana Stambolića dužnosti predsednika Predsedništva SR Srbije. Predsedništvo SR Srbije očekuje da će drug Ivan Stambolić u daljem radu dati doprinos izvršavanju zadataka Predsedništva Srbije.

U radu sednice, pored svih članova Predsedništva, učestvovali su član Predsedništva SFRJ Nikola Ljubičić i predsednici organa društvenopolitičkih organizacija Republike“". ${ }^{4}$

Istoga dana Republička kandidaciona konferencija Socijalističkog saveza „jednoglasno je utvrdila predlog“ da kandidat za predsednika Predsedništva bude general Petar Gračanin, narodni heroj i nosilac Partizanske spomenice 1941. Gračanin je u tom trenutku bio član Predsedništva CK SK Srbije, a njegovim izborom Milošević je još jednom hteo da potvrdi primat partije nad državom. Tako je nekadašnji načelnik Generalštaba JNA predložen na čelnu državnu funkciju, u nadi „da će svojim revolucionarnim iskustvom bitno

41 Наведено према: Славољуб Ђукић, Како се gойoguо вођа. Борба за власти у Србији йосле Јосийа Броза, (Београд: Филип Вишњић, 1992), 258-259.

${ }^{42}$ I. Stambolić, Put u bespuće, 262.

${ }^{43}$ Isto.

44 „Иван Стамболић разрешен дужности“, Борба, 15. 12. 1987, 1. 
doprineti ostvarivanju ustavnih funkcija Predsedništva pred kojim su sada veoma odgovorni zadaci“ ${ }^{45}$

Milošević nije gubio vreme. Već sutradan (15. decembra) Skupština Srbije, na sednici svoja sva tri veća, izabrala je Gračanina za člana državnog Predsedništva. Obrazlažući predlog za izbor Gračanina, Dragan Milićević je u ime Republičke kandidacione konferencije izjavio kako su u Srbiji „obavljene široke konsultacije nakon kojih je usledio postupak koji je bio javan i demokratski“. Od ukupno 271 prisutnog delegata, za Gračanina je glasalo njih 251. Zatim je general dao svečanu izjavu. ${ }^{46}$

Iz obrazloženja Dragana Milićevića proizilazi da se 11. decembra sastala Komisija Predsedništva Socijalističkog saveza za kadrove i odlučila da se Gračanin kandiduje za člana Predsedništva, što znači da je tajni sastanak o kome piše Stambolić održan između 5. i 11. decembra. Milićević je još naglasio da je „takav izbor potpuno razumljiv jer je reč o čoveku dobro poznatom radnim ljudima, čoveku koji je uspešno obavljao izuzetno odgovorne dužnosti u JNA i SKJ". ${ }^{47}$

Ostalo je još samo da se Petar Gračanin i formalno izabere za predsednika Predsedništva. To je učinjeno 22. decembra 1987. godine. Simbolika je bila očigledna. Ivan Stambolić je i dalje ostao član Predsedništva. Gračanin je bio šesti po redu predsednik Predsedništva od kada je ovaj forum ustanovljen. Prvi je bio Dragoslav Marković, a zatim su birani Dobrivoje Vidić, Dušan Čkrebić, Nikola Ljubičić i sam Stambolić. Sednici su prisustvovali „najviši rukovodioci Republike i Beograda“ na čelu sa Miloševićem. Gračaninu je na izboru prvi čestitao - Nikola Ljubičić. ${ }^{48}$

Smenama je Milošević postigao šta je želeo - stvorio je utisak u javnosti da više ne postoje nedodirljivi funkcioneri, da je počeo proces „„̌išćenja vlasti“ od onih koji su „loše radili“. Sama ta situacija mogla je da u narodu, već naviklom na večitost postojeće vlasti, stvori nadu kako će se stanje promeniti na bolje, bez krupnijih izmena sistema, za šta još dugi niz godina neće postojati spremnost.

Ironija istorije ogleda se u činjenici da Stambolićev pad nikoga posebno nije uzbudio na zapadu Jugoslavije. Konfederalizam je već duboko zaživeo i svako je gledao svoja posla, a svaka akcija iz Srbije merena je dvostrukim standardima, bez obzira od koga dolazila. Federalni vrh je smatrao da je Miloševićevom pobedom u Srbiji pobedila pravoverna, tvrda komunistička

\footnotetext{
45 „Петар Грачанин кандидат за председника“, Борба, 15. 12. 1987, 1.

46 „Петар Грачанин члан Председништва СРС“, Борба, 16. 12. 1987, 1.

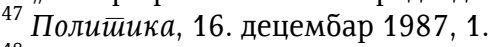

48 „Седница Председништва СР Србије“, Политиика, 23. 12. 1987, 6.
} 
linija. Verovalo se i da će nova srpska garnitura manje insistirati na korenitim društvenim reformama, što bi bilo pogubno za okoštalu partijsku birokratiju. Posebno je kadrovima iz Bosne i Hercegovine bila bliska Miloševićeva titoistička odanost, hrvatsko vođstvo je čak imalo predstavu o Miloševiću kao „komunističkom kozmopolitu“, nasuprot „nacionalnom komunisti“ Ivanu Stamboliću. Stipe Šuvar, tadašnji predsednik Predsedništva CK SKJ, Miloševićev trijumf je video kao pobedu snaga koje su „obećavale komunističku akciju protiv nacionalizma i obračun s čaršijskim nacionalizmom". ${ }^{49}$

U političkoj oligarhiji van „uže Srbije“ Stambolić je doživljavan kao opasan protivnik i na pitanju međunacionalnih odnosa i na pitanju ideologije. Osim što je doživljavan kao srpski nacionalista, smatralo se i da je popustljiv prema „antikomunističkoj ideologiji“. Tretiran je kao težak protivnik, sklon radikalnim promenama ekonomskog i političkog sistema. Na drugoj strani, Miloševića nisu smatrali opasnim čak ni posle prvih praktičnih rezultata njegove politike (čistke u Srbiji i prvi pokreti masa). Konzervativizam federalnog vrha i osećaj da je Milošević „njihov čovek“ presudno su uticali na Miloševićevo preuzimanje vlasti u Srbiji.

Tako je u Zagrebu pisano da u Srbiji i većina i manjina imaju isto mišljenje o suštinskim problemima, da između Dragoslava Markovića, Ivana Stambolića i Slobodana Miloševića nema suštinskih idejnih razlika, da su sva trojica zapravo izdanci jedne te iste politike, a stvar je samo u „finesama i istovrsnim ambicijama". Iako se isticalo da je Stambolić bio dosledan borac protiv srpskog nacionalizma, ipak je suština njegove pogrešne politike viđena u borbi za obnavljanje srpske državnosti: „Nije li upravo za vrijeme njegove vladavine i kritike nacionalizma teza o zaostajanju Srbije dobivala i podršku onih koji su tvrdili da je Srbija sve ono što je dobivala u ratovima gubila u miru? Nije li to bio period kada je srpski nacionalizam istupao legitimno i gotovo neometano, kada su se kao saveznici nudili i spasioci iz Francuske 7? Nisu li u njegovo vrijeme rasprave o Ustavu dovedene do usijanja, sve do zahtjeva o ukidanju autonomija? Nije li u to vrijeme Bulatović nametan jugoslavenskim piscima, iako je bilo jasno da ga većina ne želi? Nisu li izdanja 'Politikine' kuće, kojoj je na čelu navodno bio njegov čovjek, raspirivala srpski nacionalizam, otvoreno sijala nepovjerenje $\mathrm{u}$ kosovsko rukovodstvo, stvarala antialbansko raspoloženje, do kraja politizirala svaki eksces? Mogli bismo nabrojati još mnogo toga što je govorilo o bujanju srpskog nacionalizma u Stambolićevo vrijeme, što je u direktnoj suprotnosti s njegovim javnim istupima“. ${ }^{50}$

${ }^{49}$ Navedeno prema: Dejan Jović, Jugoslavija - država koja je odumrla. Uspon, kriza i pad Četvrte Jugoslavije 1974-1990, (Beograd: Samizdat B92; Zagreb: „Prometej“, 2003), 405.

${ }^{50}$ Gojko Marinković, „Kraj Stambolićeve frakcije“, Danas, 22. 12. 1987, 21. 
Ironija istorije ogleda se $u$ činjenici da su Miloševića podržala i rukovodstva srpskih pokrajina, jer su ga smatrala idejno bližim. On sam tada nije potezao osetljiva pitanja o položaju pokrajina, o jedinstvu i zajedništvu u Srbiji. Dokazivao je da brani Tita od liberala, kao kada se on sam nekada branio od njih. To se najbolje videlo u tumačenjima vojvođanskih političara. Živan Berisavljević je mislio da su Petar Stambolić i Dragoslav Marković izveli obračun sa liberalima da bi „omogućili prostor za afirmaciju nacionalističkim snagama“, a da je Ivan Stambolić bio samo „karika u lancu evolucije ka robustnom postavljanju srpskog nacionalnog pitanja sa neistorijske pozicije". ${ }^{51}$

Nešto umereniji bio je Boško Krunić: „Što se Ivana Stambolića tiče, ja danas mislim da bi on bio u stanju da izvede to visoko podšišivanje autonomije i Kosova i Vojvodine, a naročito Vojvodine jer je Kosovo već bilo podšišano - i na miran način i uz pomoć Jugoslavije. Milošević je to postigao silom i često suprotstavljajući se Jugoslaviji. Bilo je ljudi u Vojvodini koji su upozoravali: - Pa tu i nema nekog velikog izbora. Milošević je možda za juriš, Ivan nije, ali Ivan ima jako dobre veze i sa Slovencima i sa Hrvatima. Ja mislim da je Ivan bio temeljan političar. Bez obzira što se u nekim pitanjima odnosa u Srbiji nismo slagali, mi smo bili u stanju da po tri, četiri sata, ne znam koliko puta, odsedimo i razgovaramo, da se sukobljavamo, ali i onda da se pitamo za zdravlje i da sve ima ljudsku iskrenost. Ivan je čovek tolerantan, s razumevanjem za tuđe mišljenje, za stav, za razlike. Ume čovek da sluša. To sam poštovao". ${ }^{52}$

Iako je smatrala da se radi o još jednom staljinističkom unutarpartijskom sukobu, i srpska nacionalna inteligencija podržala je smenjivanje Pavlovića i Stambolića, jer su upravo oni najviše napadali „Memorandum“ SANU. Osim toga, oni su podržavali i Miloševićevu "spremnost" da reši kosovski problem.

\section{LITERATURA}

Antonić, SlobodanZarobljena zemlja. Srbija za vlade Slobodana Miloševića. Beograd: Otkrovenje, 2002.

Bogdanović, Bogdan. Mrtvouzice. Mentalne zamke staljinizma. Zagreb: August Cesarec, 1988.

Bondžić, Dragomir. „Osma sednica i Beogradski univerzitet". U: Slobodan Milošević - put ka vlasti. Osma sednica CK SK Srbije - uzroci, tok i posledice. Priredili Momčilo Pavlović, Dejan Jović i Vladimir Petrović,

\footnotetext{
51 „Деценија Слободана Милошевића“, Борба, 15. фебруар 1993, 9.

52 „Ко неће Власија, има Ругову“, Борба, 22. фебруар 1993, 9.
} 
149-160. Beograd: Institut za savremenu istoriju; Stirling: Centar za proučavanje evropskog susedstva, 2008.

Ђукић, Славољуб. Како се gойoguо вођа. Борба за власти у Србији йосле Јосийа Броза. Београд: Филип Вишњић, 1992.

Jović, Dejan. Jugoslavija - država koja je odumrla. Uspon, kriza i pad Četvrte Jugoslavije 1974-1990. Beograd: Samizdat B92; Zagreb: „Prometej“, 2003.

Jović, Dejan. „Osma sjednica: uzroci, značaj, interpretacije“. U: Slobodan Milošević - put ka vlasti. Osma sednica CK SK Srbije - uzroci, tok i posledice. Priredili Momčilo Pavlović, Dejan Jović i Vladimir Petrović, 33-70. Beograd: Institut za savremenu istoriju; Stirling: Centar za proučavanje evropskog susedstva, 2008.

Nikolić, Kosta. „Osma sednica - kraj borbe za Titovo nasleđe u Srbiji“. U: Slobodan Milošević - put ka vlasti. Osma sednica CK SK Srbije - uzroci, tok i posledice. Priredili Momčilo Pavlović, Dejan Jović i Vladimir Petrović, 121-148. Beograd: Institut za savremenu istoriju; Stirling: Centar za proučavanje evropskog susedstva, 2008.

Petrović, Vladimir. „Uloga medija u učvršćenju vlasti Slobodana Miloševića“, Istorija 20. veka, 2 (2013), 183-204.

Stambolić, Ivan. Put u bespuće: odgovori Ivana Stambolića na pitanja Slobodana Inića. Beograd: Radio B 92, 1995.

Kosta Nikolić

\section{REMOVAL OF IVAN STAMBOLIĆ FROM THE POSITION OF THE PRESIDENT OF THE PRESIDENCY OF THE SOCIALIST REPUBLIC OF SERBIA IN 1987}

\section{Summary}

Slobodan Milošević started a wide political campaign in the late fall of 1987 in order to politically eliminate Ivan Stambolić. Even after the Eighth Session Milošević wanted to send a clear message to all of his adversaries - he is the absolute leader of the Serbian communist party and the Serbian nation. To that end he evoked the necessity of the „unity of socialist forces" in order for the Serbian society to quickly emerge from a political, economic and moral crisis. At the same time, he was creating an image of himself as a man of action that doesn't hesitate and does not waste time making „useless" conversations. Through a well organized political action, Ivan Stambolić was removed from the most important state function in 
Serbia, and by doing so Milošević suffocated every opposition inside the Serbian communist party. As a leader, his offer was similar to Tito's: egalitarianism, a simplified picture of the world and how it works, a new religion (belonging to a class was replaced by belonging to the nation), and - a vision of a common enemy. Dangerous channel was opened for collective venting of frustrations of the people. First among such enemies were "the forces defeated in the Eighth session“ and Serbian „bureaucrats and officials", then Albanians and politicians from Vojvodina, then the Croats and Slovenians, and finally wider range of threats within and outside Yugoslavia.

KEYWORDS: Slobodan Milošević, Ivan Stambolić, personality of cult, absolute power

\section{LA RÉVOCATION D'IVAN STAMBOLIĆ DE LA FONCTION DE PRÉSIDENT DE LA PRÉSIDENCE DE LA RÉPUBLIQUE SOCIALISTE DE SERBIE EN 1987}

\section{Résumé}

En automne 1987, Slobodan Milošević lança une grande campagne politique pour réaliser la "liquidation" politique d'Ivan Stambolić. Milošević voulait envoyer à tous ses adversaires potentiels le message clair qu'il était le leader absolu du parti communiste et de l'Etat serbes. À l'époque, il ne cessait de souligner la nécessité de "l'union des forces socialistes" pour que la société serbe puisse au plus vite sortir de la crise politique, économique et morale. Milošević était en pleine offensive alors que la VIII ${ }^{\mathrm{e}}$ session du Comité central du parti communiste était largement interprétée comme un moment-clé dans la résolution de cette crise. En même temps, il se construisait une image d'homme d'action qui n'hésitait pas et ne perdait pas de temps dans les discussions "inutiles". Par une action politique bien organisée, Ivan Stambolić fut révoqué de la fonction officielle la plus importante en Serbie et Milošević étouffa toute opposition possible au sein du parti communiste serbe. Au peuple serbe épuisé par les crises, il offrit la même chose que Tito autrefois : un leader, l'égalitarisme, une vision simplifiée du monde et de ses relations, l'appartenance à la nouvelle religion (l'appartenance à la classe était remplacée par l'appartenance à la nation), et l'ennemi. Avec lui, sans aucun danger, la masse pouvait se débarrasser de ses propres frustrations. Le premier ennemi, c'étaient les "forces battues à la Huitième session", ensuite les "bureaucrates" et les fonctionnaires 
communistes, puis les Albanais, les "autonomistes", les Croates et les Slovènes, et enfin les "destructeurs mondiaux de la Yougoslavie".

MOTS CLÉS: Slobodan Milošević, Ivan Stambolić, culte de la personnalité, pouvoir absolu 